\title{
The effect of polyacrylamide on grass emer- gence in southcentral New Mexico
}

\author{
H.O. RUBIO, M.K. WOOD, M. CARDENAS, AND B.A. BUCHANAN
}

\begin{abstract}
Authors are former graduate student, Dept. of Anim. and Range Sci.; professor, Dept. of Anim. and Range Sci.; professor, Dept. of Experimental Statistics; associate professor, Dept. of Agronomy and Horticulure, respectively, New Mexico State University, Las Cruces 88003.
\end{abstract}

\section{Abstract}

Seeding rangeland is a challenge for rangeland scientists, especially on those soils with tendency to crusting. Although some information is available on how soil conditioners affect emergence of certain comestible crops, little is known about the effect of synthetic organic matter on grass emergence. We examined the effect of polyacrylamide, a soil conditioner, on seedling emergence of blue panicgrass (Panicum antidotale Retz.), King Ranch bluestem (Bothriochloa ischaemum [L.] Keng), sideoats grama (Bouteloua curtipendula [Michx.] Torr.), plains bristlegrass (Setaria macrostachya H.B.K.), and 'salado' alkali sacaton (Sporobolus airoides [Torr.] Torr.) under field conditions. Emergence of blue panicgrass and sideoats grama was increased with polyacrylamide applications, even at the lowest concentration (10 $\left.\mathrm{kg} \mathrm{ha}^{-1}\right)$ during summer 1987. No emergence response to polyacrylamide applications was found for King Ranch bluestem, and plains bristlegrass did not emerge in any experimental plots during summer 1987. During summer 1988, blue panicgrass and sideoats grama emergence was again increased with polyacrylamide applications. Emergence of 'salado' alkali sacaton and King Ranch bluestem was unaffected by polyacrylamide applications. Soil conditioners may be a feasible alternative for seeding some rangeland in areas where crusting is a problem.

\section{Key Words: soil conditioner, seeding}

Seeding technologies for certain rangelands have not been adequately developed, and as a consequence, large rangeland areas remain in a stage of depletion after perturbation. Development of new technologies for seeding rangelands is needed because of crusting soils that retard plant germination and emergence (Herbel et al. 1973). Soil crusting may be caused by disintegration of soil aggregates (Coughlin et al. 1973) or by chemical dispersion of clay particles (Agassi et al. 1981) that are washed into voids. After either process, wetting and drying cycles form the crust. Application of organic matter may ameliorate crusting problems. The beneficial effects of applying organic matter to soils was empirically recognized about 4,000 years ago by the Sumerians (Kramer 1963). Today, it is well known that applying organic matter, such as crop residues and manure, increases the bonding of mineral particles into water-stable aggregates (Elson 1940 and Dzhanpeisov et al. 1984), which reduces crusting. Unfortunately, in some areas, natural organic matter is either unavailable or scarce; thus, improvement of soil structure may be achieved by using synthetic polymers.

Research on synthetic soil conditioners was quite active about 4 decades ago when some researchers such as Hedrick and Mowry

\footnotetext{
Journal Article 1562 of the New Mexico Agr. Exp. Sta., Las Cruces.

The authors thank the Jornada Experimental Range Station for partial support of this research.

Manuscript accepted 28 September 1991.
}

(1952); Martin (1953); and Quastel (1954) showed the stabilizing effect of some chemicals. More recently, other researchers such as Cook and Nelson (1986) showed the beneficial effect of these chemicals in improving emergence of alfalfa (Medicago sativa L.) and sweet corn (Zea mays L.). Synthetic soil conditioners increased emergence of tomato (Lycopersicon esculentum Mill), cotton (Gossypium hirsatum L.), and lettuce (Lactuca sativa L.) seedlings (Wallace and Wallace 1986a and 1986b), and improved emergence of the grasses: sideoats grama (Bouteloua curtipendula ${ }_{[}$Michx. Torr.), alkali sacaton (Sporobolus airoides [Torr.] Torr.), and Boer lovegrass (Eragrostis chloromelas Steud.) under greenhouse conditions (Rubio et al. 1989, 1990). Chemical soil conditions may also increase infiltration (Sherwood and Engibous 1953, Lal and Greenland 1978, and Wallace et al. 1986c); reduce evaporation (Dasberg and Plaut 1964, Lishtvan et al. 1984, and Rubio et al. 1990); control erosion (Weeks and Colter 1952); improve carbon content (Dzhanpeisov et al. 1984); and, possibly, increase yield of some crops (Polyakova 1976).

Polyacrylamide (PAM) is an inexpensive soil conditioner that reduces crust formation and improves grass emergence (Rubio et al. 1989, 1990), even at low concentrations (Wallace and Wallace 1986c). Polyacrylamide is manufactured in different ionic configurations, and is usually used as a flocculating agent. This product can be applied as a solid (granules) or in a solution (liquid), which may help in seeding rangeland areas where crusting is a serious problem. However, no information is available about how polyacrylamide affects emergence of rangeland grasses under field conditions. We examined the results of applying $0,10,20$, and $40 \mathrm{~kg} \mathrm{ha}^{-1}$ of PAM ( $100 \%-5$ million molecular weight) to soil supporting no vegetation, but seeded with blue panicgrass (Panicum antidotale Retz.), King Ranch bluestem (Bothriochloa ischaemum [L.] Keng), sideoats grama, plains bristlegrass (Setaria macrostachya H.B.K.), and 'salado' alkali sacaton under field conditions. Polyacrylamide is made and sold by several firms. Polyacrylamide used in this study was from the Complete Green Co., 2066 Westwood Boulevard, Los Angeles, Calif. 90025.

Because soil water deficiency in the seed zone is often the major cause of grass seeding failures (McGinnies 1960, Osborn et al. 1967 , and McClean and Wikeem 1983), we used waterponding to collect more runoff. Dike designs were suggested by Tromble (1982), who found waterponding provides adequate soil water from 7.5 to $15-\mathrm{cm}$ deep. This is important because seeds with more water have a better opportunity to germinate, emerge, and become established. However, ponding by itself is inadequate for establishing grasses (Tromble unpublished data).

\section{Materials and Methods}

\section{General Methods}

Two field experiments were performed during summer 1987 and 1988. Both experiment sites were established at the Jornada Exper- 
imental Range Station, $37 \mathrm{~km}$ ( $33^{\circ} 11^{\prime} \mathrm{N}$ latitude) north of Las Cruces, New Mexico. This site is representative of the climate and environmental conditions of a semidesert grassland used mainly for grazing and wildlife habitat. Low and erratic rainfall, low relative humidity, and high evaporation rates occur during the summer season, July through September. Drought is common, and severe dust storms are common from February through April. Yearly rainfall average is $230 \mathrm{~mm}$ and about $52 \%$ of the rainfall occurs during summer. There are 22 different soil series on the Jornada, and microrelief changes are dynamic because of water and wind erosion. Soils have low organic carbon levels and high concentrations of calcium carbonate. Wildlife are abundant on the Jornada Experimental Range Station and, phytogeographically, this area produces a wide variety of grasses and shrubs.

Both experiments were conducted upslope from waterponding dikes designed and constructed by Tromble (1983). The dikes had a horseshoe shape, and were nested below one another progressively downslope. Each was designed to catch $250 \mathrm{~mm}$ of water, then allow excess water to spill into the next one downslope. Thus, waterponding modifies the land surface, adds supplemental water, increases water infiltration and soil water storage, and controls runoff (Tromble 1982). It is assumed that waterponding is advantageous to seedling establishment as mentioned by Tromble (1982); no soil moisture measurements were taken during this study. Because salt content was suspected to be high across all treatments, 5 soil samples were randomly collected at depths of $0-5,5-10$, $10-15,15-20,20-25$, and $25-30 \mathrm{~cm}$ at each dike. The 5 soil samples were mixed to produce a composite sample for each depth at each dike. Additional soil samples at the same depths were randomly taken in bare soil without both dikes and vegetation. Electrical conductivities were determined for each sample.

The dikes'catchment areas have medium surface runoff potential and moderate water and high wind erosion potential (USDASCS 1986). The soil is in the fine-silty, mixed, thermic family of Ustollic Calciorthids and belongs to the Reagan series. Ten soil samples were taken randomly from 0 to $20-\mathrm{cm}$ depth in the diked areas, mixed, and a sample analyzed in the Soil and Water Testing Laboratory at New Mexico State University. Soil pH was 7.45 , electrical conductivity was $5.14 \mathrm{mmhos} \mathrm{cm}^{-1}$, calcium carbonate was $17.20 \%$, organic carbon content was $1.03 \%$, nitrogen was 122.0 $\mu \mathrm{g} \mathrm{ml}^{-1}$, phosphorus was $8.3 \mu \mathrm{g} \mathrm{ml}^{-1}$, potassium was $50.8 \mu \mathrm{g} \mathrm{ml}^{-1}$, sodium was $2.82 \mu \mathrm{g} \mathrm{ml}^{-1}$, and bulk density was $1.47 \mathrm{~g} \mathrm{~cm}^{-3}$.

Seeds of sideoats grama, alkali sacaton and Boer lovegrass were donated by the Jornada Experimental Range Station (USDAARS). Seeds of blue panicgrass and plains bristlegrass were obtained from the USDA-SCS Plant Materials Center, Tucson, Ariz., and seeds of 'salado' alkali sacaton were obtained from the USDA-SCS Plant Materials Center at Los Lunas, N.M. Germination tests were used to determine germination percentages of the seeds before planting. Germination percentages were $36,60,25,69$, 34 , and $50 \%$ for alkali sacaton, sideoats grama, blue panicgrass, King Range bluestem, plains bristlegrass and 'salado' alkali sacaton, respectively.

\section{Summer 1987}

Before seeding, dikes were establishd with a motor grader to assure water would spill from the highest dike to the lower ones. Catchment areas were disked to break the soil surface and prepare the seedbed. Treatments consisted of polyacrylamide applications at 10,20 , and $40 \mathrm{~kg} \mathrm{ha}^{-1}$ and the control $\left(0 \mathrm{~kg} \mathrm{ha}^{-1}\right)$. Four perennial grasses were tested in the 1987 trial, namely blue blue panicgrass, plains bristlegrass, King Ranch bluestem and sideoats grama. A 4 $\times 4$ factorial arrangement of treatments (4 PAM rates and 4 grasses) was employed. Four dikes were used, and each dike was a replication. The experimental design was a randomized, completeblock design with 4 replications.
Each treatment plot was 3-m long and 2-m wide, with rows 20-cm apart. Based on germination responses of seed, 2,000 panicgrass, 1,660 plains bristlegrass, $730 \mathrm{King}$ Ranch bluestem, and 830 sideoats grama seeds were planted in each plot to expect 500 seedlings of each grass per plot. Each of the 10 rows per plot received 200 seeds of blue panicgrass, 165 seeds of plains bristlegrass, 73 seeds of King Ranch bluestem, and 83 seeds of sideoats grama. Anticipated seedlings were about 500 per plot ( 50 seedlings per row). Seeds were planted by hand in a marked groove at about 0.5 to $1.0-\mathrm{cm}$ depth (Cooperative Extension Service 1986), and distributed along the rows as evenly as possible.

Polyacrylamide was weighed and solutions were prepared for the different treatments by dissolving PAM in 10 liters of water. After seeding, PAM solutions were applied over the soil surface, using 10-liter watering cans. Control treatments were watered with 10 liters of water after planting. A barbed-wire fence excluded grazing by sheep and cattle. Emerged seedlings were counted 30 days after the first rainfall and runoff and emergence percentage was calculated.

\section{Summer 1988}

This experiment was similar to that reported for summer 1987. In general, the same grass species as those used in summer 1987 were used; however, 'salado' alkali sacaton replaced plains bristlegrass because none of the plains bristlegrass seed germinated in any of the summer 1987 plots. Seed planting methodology was the same as that reported for summer 1987, except 5 rows (not 10) were used per plot (distance between rows was $40 \mathrm{~cm}$ ). Consequently, the number of planted seeds per row (and in total per plot) was half of that in summer 1987. Each row received 200, 100, 73, and 83 seeds of blue panicgrass, 'salado' alkali sacaton, King Ranch bluestem and sideoats grama, respectively. Each plot in each block was seeded with $1,000,500,365$, and 415 seeds of blue panicgrass, 'salado alkali sacaton, King Ranch bluestem and sideoats grama, respectively, to anticipate 250 seedlings in each plot.

Polyacrylamide applications were $0,10,20$, and $40 \mathrm{~kg} \mathrm{ha}^{-1}$. Application of this soil conditioner to soil was similar to that reported for summer 1987. A $4 \times 4$ factorial arrangement of treatments (4 PAM rates and 4 grass species) in a randomized, complete-block design with 4 replications was used. Each dike was a replication. Emerged seedlings were counted 30 days after the first rainfall, and percentage emergence was calculated. Analysis of variance was performed for each species, and contrasts were used to determine linear, quadratic, and cubic effects. Differences were noted at the 0.05 level of significance.

\section{Results and Discussion}

\section{Summer 1987}

The first runoff accumulated on the diked areas 17 days after planting. Blue panicgrass seedling emergence was significantly affected by PAM applications. About 3\% emergence occurred on control plots in comparison with 11,16 , and $19 \%$ in plots treated with 10,20 , and $40 \mathrm{~kg} \mathrm{ha}^{-1}$ of PAM, respectively. A quadratic relationship between PAM applications and seedling emergence existed for blue panicgrass (Fig. 1). Plains bristlegrass did not emerge in any of the plots so no statistical analysis was performed. Seedling emergence of King Ranch bluestem was not affected by PAM applications. Only $7 \%$ of the seedlings emerged with the highest PAM concentration. Control plots and treatments with 10 and $20 \mathrm{~kg} \mathrm{ha}^{-1}$ PAM application reached only about 5, 6, and 6\% emergence, respectively. Sideoats grama seedling emergence was improved with PAM applications. About $21 \%$ emergence was found for this grass with the highest PAM concentration $(40 \mathrm{~kg}$ $\mathrm{ha}^{-1}$ ), in comparison with only $3 \%$ in control treatments. Treatments with 10 and $20 \mathrm{~kg} \mathrm{ha}^{-1}$ had reached about 7 and $18 \%$ seedling 


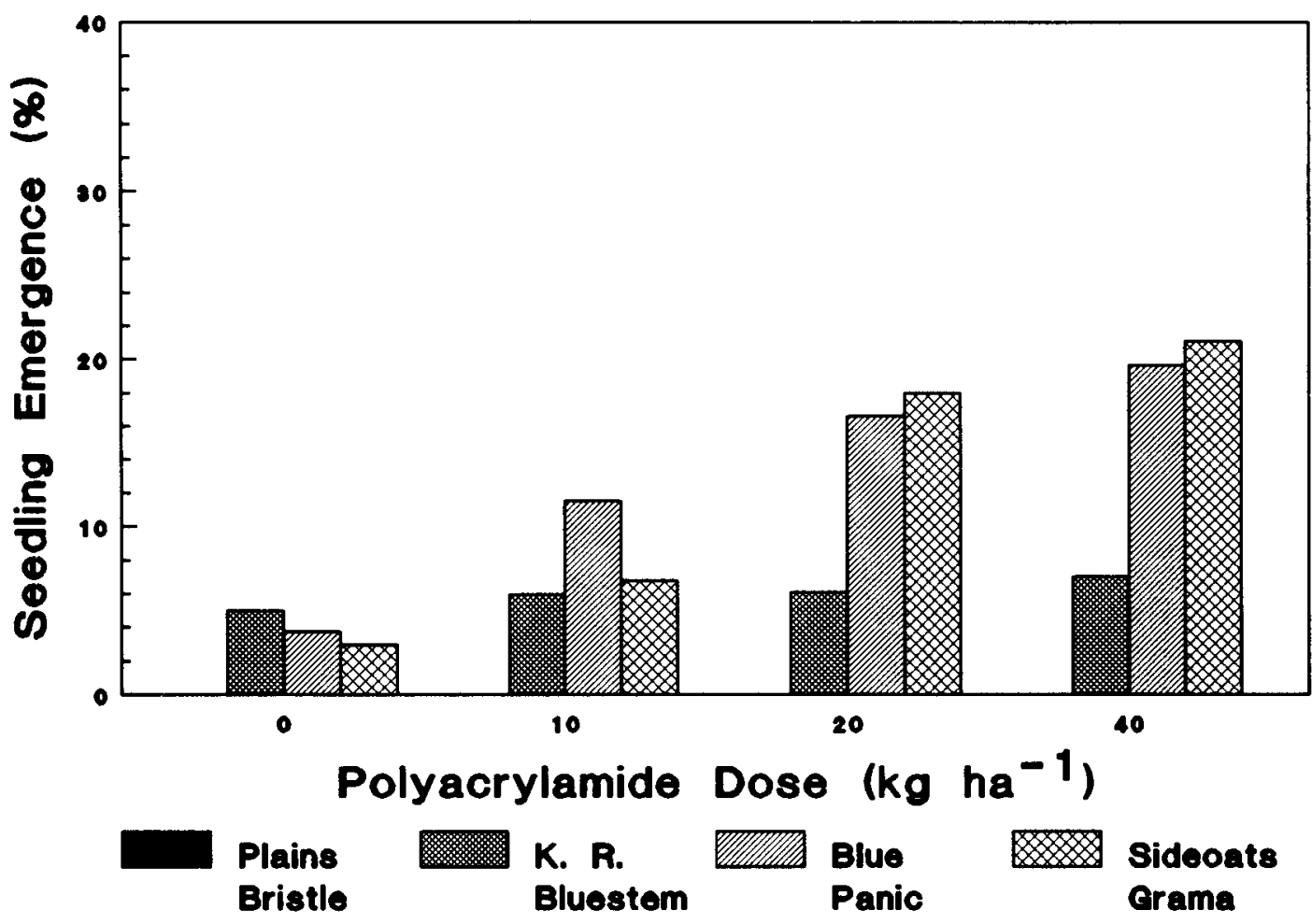

Fig. 1. Mean percentage seedling emergence for 4 grass species and 4 polyacrylamide doses in 1987, Jornada Experimental Range, New Mexico.

\section{8}

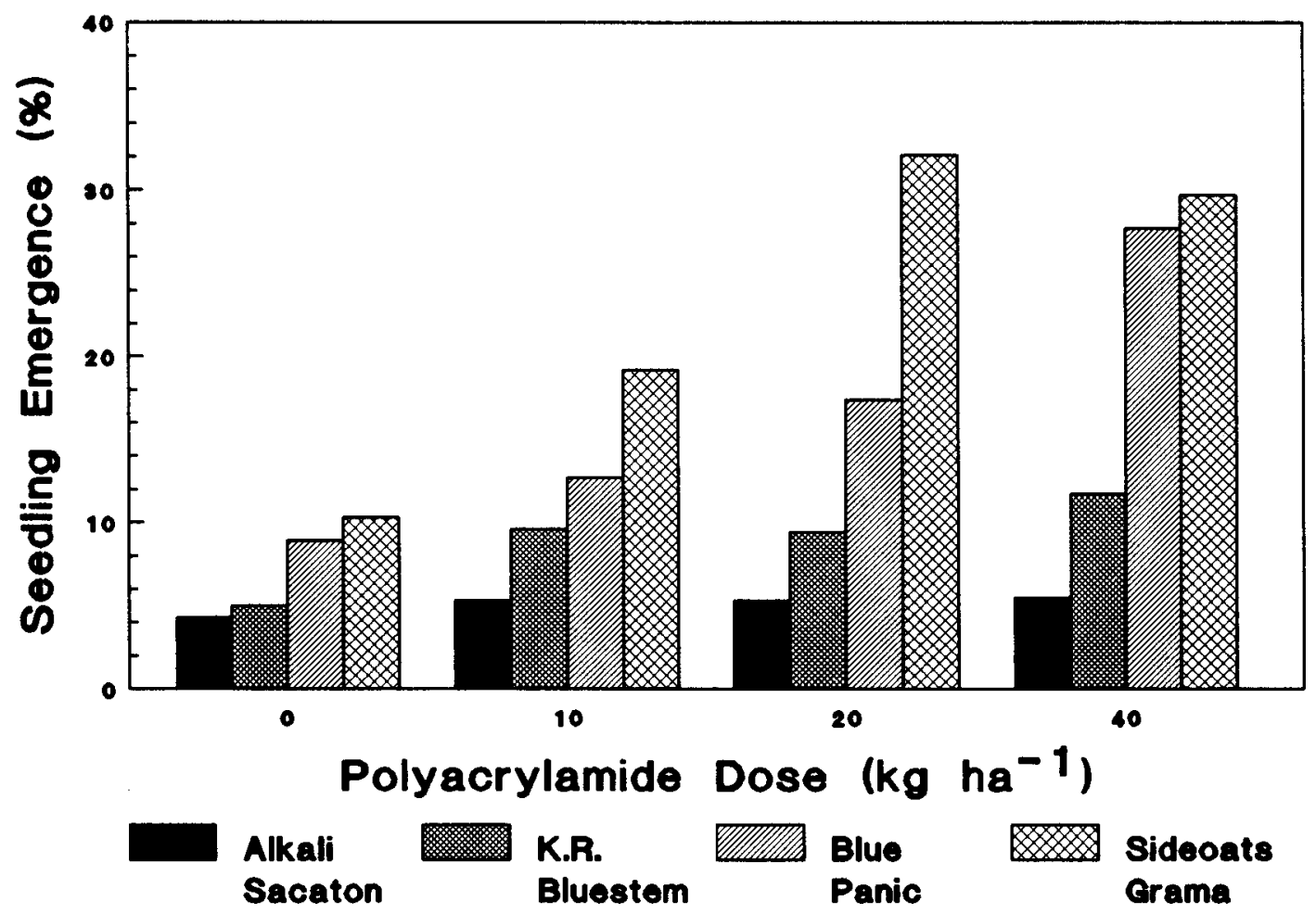

Fig. 2. Mean percentage seedling emergence for 4 grass species and 4 polyacrylamide doses in 1988, Jornada Experimental Range, New Mexico. 
emergence, respectively. In general, as PAM rates increased, seedling emergence increased for sideoats grama. A linear trend was evident for seedlings of this grass spcies (Fig. 1).

Although seedlings of blue panicgrass, King Ranch bluestem, and sideoats grama were noticed, these seedlings dessicated rapidly, and all plants were dead about 2 months after emergence. This dessicating effect had been previously reported by Rubio et al. $(1989,1990)$ in the same grass species with this soil series under greenhouse conditions. High salt content in the soil, associated with low precipitation and high evaporation rates, caused a negative synergistic effect. Although the waterponding dikes increased water content in the soil, it was not enough to alleviate the detrimental effect of salts. In reality, the waterponding dikes might bring salts to the soil surface where they interfere with germination and emergence of some species.

Dike 2 and dike 4 had the highest salt content at $0-10 \mathrm{~cm}$-depth, while dike 1 and dike 3 had the highest salt accumulation at 20-25 $\mathrm{cm}$ and 20-30-cm depth, respectively. The highest salt content was present in dike 2 with 20.9 mmhos $\mathrm{cm}^{-1}$ and $0-5-\mathrm{cm}$ depth. In general, dikes 3 and 4 were less affected by salt accumulation. Similar electrical conductivities were found for soil samples of the dikes 3 and 4 with respect to soil samples of bare soil without dikes. Electrical conductivities in bare soil without dikes ranged from 4.1 (0-5-cm depth) to $1.8 \mathrm{mmhos} \mathrm{cm}^{-1}$ (25-30-cm depth). However, these results showed that dikes 1 and 2 had, at all measured depths, salt contents in excess of the definition for a saline soil (Richards 1954).

Salty clay soil is recognized as a major problem for rangeland seeding. In general, soils without vegetation comprise small areas where performances of different species should be tested. In addition, PAM, as well as other soil conditioners, may be a valuable amendment for seeding rangeland areas.

\section{Summer 1988}

Control plots reached about $9 \%$ emergence averaged across species, while plots treated with 10,20 , and $40 \mathrm{~kg} \mathrm{ha}^{-1}$ PAM reached about 13,17 , and $27 \%$ emergence, respectively. Seedling emergence of blue panicgrass was significantly increased with PAM applications. Contrasts indicated a strong linear relationship between PAM applications and seedling emergence of blue panicgrass (Fig. 2). 'Salado' alklai sacaton and King Ranch bluestem seedlings were unaffected by PAM applications. However, the highest percentage of seedlings for these 2 grasses was found with application of $40 \mathrm{~kg} \mathrm{ha}^{-1}$ of PAM.

Seedlings of sideoats grama, as expected, were significantly improved with PAM applications. Contrasts indicated a positive linear relationship between PAM applications and seedlings of sideoats grama. The highest percentage emergence for sideoats grama ocurred with $20 \mathrm{~kg} \mathrm{ha}^{-1}$ of PAM, while the lowest percentage was found on control treatments. As PAM rates increased, seedling emergence also increased until $20 \mathrm{~kg} \mathrm{ha}^{-1}$ was applied (Fig. 2).

Annual and perennial weeds were identified in the plots for both summers. Among the most abundant annual weeds were Russian thistle (Salsola iberica Sennen and Pau) and spectacle-pod (Dithyrea wislizeni Engelm.), while the most abundant perennials were hog potato (Hoffmanseggia densiflora Benth.), globemallow (Sphaeralcea spp.), and silverleaf nightshade (Solanum elaeagnifolium Car.). It is noteworthy that their survival was longer than that of the grasses tested. Perhaps weed species or annual grasses can be employed as a nurse crop to aid in the seedling survival of perennial grasses.

A comparison of results of the summer 1987 and with summer 1988 indicated more seedling emergence was obtained in the summer 1988. Percentage of seedling emergence of blue panicgrass was higher in summer 1988 than in summer 1987. The same trend was evident for sideoats grama. This effect may be related to the weather pattern; the experiment in summer 1988 received the first rainfall and runoff 1 day after planting, so seeds began to germinate immediately after seeding. It was, therefore, noted that 1 week after planting, some seeds came up and became visible in a short period of time. Unfortunately, many seedlings of both sideoats grama and blue panicgrass died about $\mathbf{4 5}$ days after emergence.

Although water-soluble PAM improved emergence of certain grasses under field conditions, further research should be conducted to examine the usefulness of cross-linked polyacrylamides, which are water-insoluble. Water-insoluble polyacrylamides swell in the presence of water and may improve the soil water status, allowing for seedling emergence, establishment, and subsequent growth. Applications of these kinds of polymers at different depth layers of the soil profile, and their effect in the different depth layer, should be tested because the main effect of PAM is concentrated in the soil surface $(0$ to $5 \mathrm{~cm}$ ) rather than in deeper layers (Mitchell 1986).

Another concern is the possible interaction of salt concentration with soil conditioners. Food and Agriculture Organization (1977) recommended a study on the effect of soil conditioners on plant growth; they further suggested that salty soils should be studied carefully because the effect of different soil conditioners will depend on type of salt and salt concentration. Therefore, greenhouse studies as well as field experiments should be conducted using different soil conditioners as soil amendments in soils with different type of salts.

Based on our results, we conclude that side oats grama and blue panicgrass should be considered as potential grasses for seeding depleted areas in southern New Mexico in conjunction with PAM, but further research is required to improve survival of these grasses under salty conditions in clay soils after emergence. Research on cultural practices as well as management practices should be performed.

\section{Literature Cited}

Agasi, M., I. Shainberg, and J. Morin. 1981. Effect of electrolyte concentration and soil sodicity on infiltration rate and crust formation. Soil Sci. Soc. Amer. J. 45:848-851.

Cook, D.F., and S.D. Nelson. 1986. Effect of polyacrylamide on seedling emergence in crust forming soils. Soil Sci. 141:328-333.

Cooperative Extension Service. 1986. Seeding New Mexico rangeland. New Mexico State Univ. Circular 525.

Doughlin, K.J., W.E. Fox, and J.D. Hughes. 1973. Aggregation in swelling clay soils. Australian J. Soil Res. 11:133-141.

Dasberg, S., and Z. Plaut. 1964. The effect of soil additions of hexadecanol and rohagit on soil evaporation and the transpiration and growth of bean plants. Isreal J. Agr. Res. 14:145-151.

Dzhanpelsov, R.D., N.S. Popova, Z.G. Akkulova, L.A. Kricheskiy, T.M. Sokolova, A. Ye. Marchenko, and A.R. Ramazanova. 1984. Soil science and chemical-mineralogical institutes, Academy of Sciences of the Kazakh SSR. Study of new polymeric soil conditioners based on the humic acid of coal. Soviet Soil Sci. 16:83-89.

Elson, J.A. 1940. A comparison of the effect of certain cropping and fertilizer and manuring practices on soil aggregation of dunmore silt loam. Soil Sci. 50:339-355.

Food and Agriculture Organization. 1977. Organic materials and soil productivity. Soil Bulletin 35 .

Hedrick, R.M., and D.T. Mowry. 1952. Effect of synthetic polyelectrolytes on aggregation, aeration, and water relationships of soils. Soil Sci. 73:427-441.

Herbel, C.H., G.H. Abernathy, C.C. Yarbrough, and D.K. Gardner. 1973. Rootplowing and seeding arid rangelands in the southwest. J. Range Manage. 26:193-197.

Kramer, S.N. 1963. The Sumerians. Their history, culture, and character. The Univ. of Chicago Press, Chicago.

Lal, R., and D.J. Greenland. 1978. Effect of soil conditioners and initial water potential of a vertisol on infiltration and heat of wetting. In Emerson, W.W., R.D. Bond, and A.R. Dexter (Eds). 1978. Modification of Soil Structure. John Wiley \& Sons, N.Y. 
Lishtvan, 1.I., A.A. Terent'yev, A.J. Sorokin, A.M. Abramets, V.S. Brezgunov, and A.M. Kushnir. 1984. Change in the hydrophysical properties of peat-bog soils after application of hydrolized polacrylonitrile. Soviet Soil Sci. Pochvovedeniye 16:116-121.

Martin, W.P. 1953. Status report on soil conditioning chemicals. I. Soil Sci. Soc. Amer. Proc. 17:1-9.

McGinnies, W.J. 1960. Effects of moisture stress and temperature on germination of six range grasses. Agron. J. 52:159-162.

McClean, A., and S.J. Wikeem. 1983. Effect of time of seeding on emergence and long-term survival of crested wheatgrass in British Columbia. J. Range Manage. 36:694-700.

Mitchell, A.R. 1986. Polyacrylamide application in irrigation water to increase infiltration. Soil Sci. 141:353-358.

Osborn, J., J. Letey, L.F. DeBano, and E. Terry. 1967. Seed germination and establishment as affected by non-wettable soils and wetting agents. Ecology 48:494-497.

Polyakova, Y.Y. 1976. Polymer-soil conditioners and nitrogen fertilizers. Soviet Soil Sci. 8:443-446.

Quastel, J.H. 1954. Soil conditioners. Annu. Rev. Plant Physiol. 5:75-92.

Richards, L.A. (Ed). 1954. Diagnosis and impovement of saline and alkaline soils. USDA Agr. Handb. 60.

Rubio, H.O., M.K. Wood, M. Cardenas, and B.A. Buchanan. 1989. The effect of polyacrylamide on seedling emergence of three grass species. Soil Sci. 148:355-360.
Rubio, H.O., M.K. Wood, M. Cardenas, and B.A. Buchanan. 1990. Seedling emergence and root elongation of four grass species and evaporation from bare soil as affected by polyacrylamide. J. Arid Environ. 18:33-41.

Sherwood, L.V., and J.C. Engibous. 1953. Status report on soil conditioning chemicals II. Soil Sci. Soc. Amer. Proc. 17:9-16.

Tromble,J.M.1982. Waterponding for increasing soil water on arid rangelands. J. Range Mange. 35:601-603

Tromble, J.M. 1983. Rangeland ponding dikes: Design criteria. J. Range Manage. 36:128-130.

USDA-SCS. 1986. Soil Survey of Dona Ana County Area New Mexico. USDA-SCS in cooperation with USDI-BLM and New Mexico Agr. Exp. Sta.

Wallace, A., and G.A. Wallace. 1986a. Effect of polymeric soil conditions on emergence of tomato seedlings. Soil Sci. 141:321-323.

Wallace, A., and G.A. Wallace. 1986b. Effects of soil conditioners on emergence and growth of tomato, cotton, and lettuce seedlings. Soil Sci. 141:313-316.

Wallace, A., and G.A. Wallace. 1986c. Effect of very low rates of synthetic soil conditioners on soils. Soil Sci. 141:324-327.

Wallace, A., G.A. Wallace, and A.M. Abouzamzam. 1986. Efects of soil conditioners on water relationships in soils. Soil Sci. 141:346-351.

Weeks, L.L.E., and W.E. Colter. 1952. Effect of synthetic soil conditioners on erosion control. Soil Sci. 73:473-484. 